Vol. 19(2010): 223-232.

\title{
The influence of raw grass pea (Lathyrus sativus L.) seeds on growth performance and biochemical and haematological parameters in the blood of grower-finisher pigs
}

\author{
Anna Winiarska-Mieczan* and Małgorzata Kwiecień \\ Institute of Animal Nutrition, University of Life Sciences, Akademicka 13, 20-950 Lublin, Poland, \\ *email:amieczan@poczta.onet.pl
}

\begin{abstract}
The aim of the present study was to examine the influence of raw seeds of grass pea (Lathyrus sativus L.) in feed mixtures for grower-finisher pigs on growth performance, and biochemical and haematological parameters in their blood, as well as on the weight of the liver and the kidney. The experiment was performed on 96 grower-finisher pigs of (Polish Landrace $\times$ Polish Large White) $\times$ Pietrain, weighing from 25 to ca. $100 \mathrm{~kg}$. The pigs were divided into four diet groups. The feed compound of the control group contained extracted soybean meal. In experimental groups soybean meal protein was replaced by raw grass pea seeds in quantities of $50 \%$ in grower and/or finisher diet, and $100 \%$ in both fattening period. The use of raw grass pea seeds amounting to $50 \%$ of protein feeds in finisher diet did not result in lower growth performance in comparison to the control group. However, the fatteners fed grass pea seeds amounting to $50 \%$ of protein feedstuffs in both fattening periods revealed the highest feed and energy intake per kg of live weight gain, compared to the group feed grass pea only in the second phase of the fattening period. A higher share of grass pea seeds in the mixture led to weaker growth performance and carcass characteristics. Hypertrophy of kidney and liver was noted in the animals which were fed with raw seeds of grass pea amounting to $100 \%$ of protein feeds. Also, hyperactivity of ALAT, ASAT and alkaline phosphatase was observed in the animals' serum. No negative influence of applying raw seeds of grass pea amounting up to $50 \%$ of protein feeds in grower and/or finisher periods on the parameters examined was noted.
\end{abstract}

Key-words: Lathyrus sativus, grower-finisher pigs, growth performance, carcass characteristics, blood parameters 
Winiarska-Mieczan and Kwiecień. Influence of grass pea seeds on pig performance and blood parameters

\section{Introduction}

The seeds of grass pea can provide a good and inexpensive source of protein for pigs. A factor which limits their usefulness is the presence of $\beta$-ODAP ( $\beta$-N-oxalyl-diaminopropionic acid) neurotoxin which causes a disease known as lathyrism or neurolathyrism, occurring symptoms as paralysis of the leg muscles, muscular rigidity and weakness (Lambein et al. 1993, Jyothi et al. 1998, Getahun et al. 1999, Pratap Rudra et al. 2004, Kuo et al. 2007), as well as a range of other anti-nutrient substances, such as protease inhibitors, lectins, tannins and phytinians (Ramachandran et al. 2005, Sharma et al. 2003). Extrusion of the seeds results in limiting the activity of these toxins (Grela et al. 2001, Ramachadran and Ray 2004), yet this is a costly procedure. Own studies (Winiarska-Mieczan 2002) revealed that an increased share of raw seeds of grass pea in the mixture for grower-finisher pigs led to poorer production effects, although raw seeds of grass pea may be used in the volume of $20 \%$ of the dose in the finisher period of fattening. Castell et al. (1994) observed that using up to $15 \%$ in the first stage, and no more than $20 \%$ of raw seeds of grass pea in the second stage of fattening does not lead to any significant decrease in the rate of grower-finisher pigs' weight gain or in any other production, physiological and biochemical parameters. The usage of raw grass pea seeds in the quantity of $15 \%$ in growing and 30\% in finishing period of pigs fattening did not induce any significant changes in fatty acid profile and sensory properties of the adductor and longissimus dorsi muscles (Winiarska-Mieczan 2010). However, it is necessary to examine if raw seeds of grass pea given to fattening pigs in the grower and/or finisher periods do not negatively affect the biochemical blood parameters, leading thus to deteriorating health of the animals.

The present study aimed to examining the influence of raw seeds of grass pea in feed mixtures for grower-finisher pigs on growth performance, and biochemical and haematological parameters of their blood, as well as on the weight of their liver and kidneys.

\section{Materials and Methods}

\section{Animals and feeding}

The experiment was conducted on (Polish Landrace $\times$ Polish Large White) $\times$ Pietrain pigs, from $25 \mathrm{~kg}$ up to ca $100 \mathrm{~kg}$ body weight (BW). The pigs were slaughtered at approximately $100 \mathrm{~kg}$ body weight.

Ninety six pigs were assigned to four feeding groups. The animals were placed in pens of two animals. Water was provided ad libitum. Feed was administered ad libitum via automatic feeders. The pigs were given grower base diet during the fattening period of 30 through $60 \mathrm{~kg}$ of body weight and finisher during the period of 60 through 100 $\mathrm{kg}$ of body weight. The animals of group I were fed standard grower or finisher mixtures the whole experimental period (Table 1). In the grower pe-

Table 1. Experimental design.

Feeding groups

II III

$\begin{array}{ccc}\begin{array}{c}\text { Standard } \\ \text { mixture }\end{array} & \text { Standard mixture } & \begin{array}{c}\text { Raw grass pea seeds } \\ (50 \% \text { protein feed })\end{array}\end{array}$

Grower

Finisher

Standard Raw grass pea seeds

mixture $(50 \%$ protein feed $)$

Raw grass pea seeds

(50\% protein feed)

Number of piglets in the experiments

24

Number of pigs for dissection
24

$5 \mathrm{G}$

$5 \mathrm{~B}$
24

$5 \mathrm{G}$

$5 \mathrm{~B}$
IV

Raw grass pea seeds (100\% protein feed)

Raw grass pea seeds

(100\% protein feed)

24

$5 \mathrm{G}$

$5 \mathrm{~B}$

G - gilts, B - barrows 
Vol. 19(2010): 223-232.

riod of experiment the animals of group II were fed standard grower mixtures, in the finisher experimental formula, soybean meal were replaced by raw grass pea seeds (Table 2). In groups II and III, raw grass pea seeds were fed at the quantity of $50 \%$ of protein. In group IV, raw grass pea seeds were fed throughout the whole experimental period at the quantity of $100 \%$ of protein. Table 3 presents chemical composition of the protein sources used in the study.

Table 2. Ingredients (\%) and chemical composition of the control and experimental mixtures.

\begin{tabular}{|c|c|c|c|c|c|c|c|c|}
\hline & \multicolumn{8}{|c|}{ Feeding groups } \\
\hline & \multicolumn{2}{|c|}{$\mathrm{I}$} & \multicolumn{2}{|c|}{ II } & \multicolumn{2}{|c|}{ III } & \multicolumn{2}{|c|}{ IV } \\
\hline & Grower & Finisher & Grower & Finisher & Grower & Finisher & Grower & Finisher \\
\hline Wheat & 30.0 & 30.0 & 30.0 & 21.0 & 41.3 & 21.0 & 30.0 & 31.5 \\
\hline Barley & 50.55 & 55.7 & 50.55 & 59.2 & 30.55 & 59.0 & 35.75 & 44.76 \\
\hline Grass pea seeds - raw & - & - & - & 10.0 & 15.0 & 10.0 & 30.0 & 20.0 \\
\hline Soybean meal & 13.0 & 10.0 & 13.0 & 7.2 & 10.0 & 7.2 & - & - \\
\hline Blood meal & - & 1.0 & - & - & - & - & - & - \\
\hline Meat-and-bone meal & 5.0 & 1.0 & 5.0 & - & - & - & 1.0 & 1.0 \\
\hline Vitamin-mineral premix ${ }^{a}$ & 1.0 & 1.0 & 1.0 & 1.0 & 1.0 & 1.0 & 1.0 & 1.0 \\
\hline L-lysine & 0.05 & - & 0.05 & - & 0.20 & 0.15 & 0.4 & 0.26 \\
\hline DL-methionine & - & - & - & - & 0.05 & 0.05 & 0.15 & 0.08 \\
\hline Fodder salt & 0.3 & 0.3 & 0.3 & 0.3 & 0.3 & 0.3 & 0.3 & 0.3 \\
\hline Limestone & 0.1 & 0.7 & 0.1 & 0.8 & 0.7 & 0.8 & 0.5 & 0.6 \\
\hline Dicalcium phosphate & - & 0.3 & - & 0.5 & 0.9 & 0.5 & 0.9 & 0.5 \\
\hline \multicolumn{9}{|l|}{$1 \mathrm{~kg}$ feed mixture contains: } \\
\hline Dry matter, g & 879 & 881 & 880 & 877 & 882 & 880 & 880 & 881 \\
\hline Crude protein, $\mathrm{g}$ & 176 & 153 & 176 & 151 & 171 & 151 & 171 & 153 \\
\hline Crude ash, g & 34.7 & 28.9 & 34.7 & 27.1 & 27.5 & 27.3 & 27.2 & 24.9 \\
\hline Crude fibre, $g$ & 41.5 & 44.5 & 41.5 & 44.5 & 40.3 & 44.4 & 40.7 & 40.5 \\
\hline Crude fat, g & 24.2 & 21.1 & 24.2 & 18.7 & 17.6 & 18.6 & 16.7 & 18.2 \\
\hline Lysine $^{\mathrm{b}}, \mathrm{g}$ & 9.23 & 7.51 & 9.23 & 7.23 & 9.20 & 7.63 & 9.26 & 7.52 \\
\hline Methionine + cysteine $^{b}, g$ & 5.74 & 5.25 & 5.74 & 4.82 & 5.55 & 5.08 & 5.53 & 4.90 \\
\hline Calcium, $\mathrm{g}$ & 7.76 & 7.37 & 7.76 & 7.20 & 7.67 & 7.20 & 7.40 & 7.08 \\
\hline Total phosphorus, g & 6.45 & 5.10 & 6.45 & 5.04 & 6.05 & 5.03 & 6.06 & 5.19 \\
\hline $\mathrm{TIA}^{\mathrm{c}} \mathrm{mg}^{-1}$ & 0.03 & 0.02 & 0.03 & 2.15 & 4.20 & 2.11 & 6.12 & 4.19 \\
\hline$\beta$-ODAP ${ }^{\mathrm{d}}, \mu \mathrm{g}$ & 0.00 & 0.00 & 0.00 & 0.09 & 0.21 & 0.10 & 0.40 & 0.21 \\
\hline Metabolizable energy $^{\mathrm{e}}$, MJ & 12.8 & 12.6 & 12.8 & 12.6 & 12.9 & 12.6 & 12.9 & 12.8 \\
\hline
\end{tabular}


Winiarska-Mieczan and Kwiecień. Influence of grass pea seeds on pig performance and blood parameters

Table 3. Chemical composition and antinutritive factors in raw grass pea seeds and soybean meal.

\begin{tabular}{|c|c|c|c|c|c|c|c|c|c|}
\hline & \multirow[b]{2}{*}{$\begin{array}{c}\text { Dry } \\
\text { matter }\end{array}$} & \multicolumn{3}{|c|}{$\mathrm{g} \mathrm{kg}^{-1} \mathrm{DM}$} & \multicolumn{3}{|c|}{$\begin{array}{l}\text { Amino acids, g } 100 \mathrm{~g}^{-1} \\
\text { crude protein }\end{array}$} & \multicolumn{2}{|c|}{ Antinutritional factors } \\
\hline & & $\begin{array}{l}\text { Crude } \\
\text { protein }\end{array}$ & $\begin{array}{c}\text { Ether } \\
\text { extract }\end{array}$ & $\begin{array}{l}\text { Crude } \\
\text { fibre }\end{array}$ & Lys & Met & Cys & $\begin{array}{l}\mathrm{TIA}^{1} \\
\mathrm{mg}^{-1} \mathrm{DM}\end{array}$ & $\begin{array}{l}\beta-\mathrm{ODAP}^{2}, \\
\mathrm{~g} \mathrm{~kg}^{-1} \mathrm{DM}\end{array}$ \\
\hline Grass pea raw seeds & 860 & 319 & 7.81 & 59.2 & 7.15 & 1.30 & 1.12 & 15.0 & 88.4 \\
\hline Soybean meal & 869 & 460 & 21.6 & 85.8 & 6.17 & 1.61 & 1.68 & 3.20 & - \\
\hline
\end{tabular}

${ }^{1}$ Trypsin inhibitor activities; ${ }^{2} \beta$-N-oxalyl-diaminopropionic acid; $\mathrm{DM}=$ dry matter

\section{Growth performance and carcass analysis}

During the experiment the production results were analysed: daily weight gain in the grower and the finisher period of fattening, feed intake and the consumption of total protein and metabolic energy for the weight gain of $1 \mathrm{~kg}$. Pig body weight and feed consumption were measured every two weeks to assess daily live weight gain and feed intake. Feed consumption was calculated as a difference between the feed offered and this remained in the feeder. Average daily gain was measured for all pigs. Feed, protein and energy intake were determined for all pens (2-pig-pen is an experimental unit) throughout the experimental period.

Following the slaughter, a dissection of the right half carcass was performed, in accordance with the methods recommended by Polish Pig Testing Stations (SKURTCh), binding in Poland and described by Różycki (1996). The carcasses were chilled at a temperature of $2-4^{\circ} \mathrm{C}$ for 24 hours. Next, slaughter analysis parameters were determined for carcasses: their middle length $(\mathrm{cm})$, the weight $(\mathrm{g})$ of the ham, the kidney and the liver and the weight of the fat in the right carcass, the thickness of fatback and the loin eye area $\left(\mathrm{cm}^{2}\right)$. Backfat thickness was measured using a calliper connected to the computer. Backfat thickness was measured on chilled half-carcasses, at five points (accurate to $0.1 \mathrm{~cm}$ ): 1) at the thickest point over the shoulder; 2) on the back, behind the last thoracic vertebra; 3 ) over the cranial edge of $m$. gluteus medius; 4) over the middle of $m$. gluteus medius and 5) over the caudal edge of $m$. gluteus medius. For determination of loin eye area, meat samples (weighing ca. $150 \mathrm{~g}$ ) were taken from the longissimus dorsi muscle in the area between the last thoracic vertebra and the first lumbar vertebra. The loin eye area was estimated using the scanned images with computer image analysis system MultiScan Base ver. 14 application. Also, samples were taken (each weighing ca. $150 \mathrm{~g}$ ) from the kidney and liver for determination of crude protein, crude fat and crude ash.

\section{Chemical analysis}

The content of the basic chemical elements in the seeds, mixtures and tissue samples was determined with the use of standard AOAC methods (1990). Trypsin inhibitors activity was determined following the method described by Kakade et al. (1974), $\beta$-ODAP concentration was determined by the HPLC method (Kuo et al. 1995).

The blood samples were taken from each pig at the end of the growing and finishing phase, after an overnight fast. Venous blood was extracted from the cubital vein, using heparine as the anticoagulant. Samples of blood were centrifuged $\left(0.9 \% \mathrm{NaCl}, 0-4^{\circ} \mathrm{C}, 15 \mathrm{~min}, 3000 \mathrm{rpm}\right)$. Serum total cholesterol, HDL-cholesterol, triglycerides (TG), aspartate aminotransferase (ASAT), alanine aminotransferase (ALAT), alkaline phosphatase (ALP) and plasma glucose were determined by spectrophotometric methods with a Beckman DU 640 (Beckman Coulter, USA) spectrophotometer using the Cormay (Poland) test. The following haematological parameters: leucocytes and their types (lymphocytes, monocytes, basophils, neutrophils, eosinophils), erythrocytes, haematocrit and haemoglobin were determined using Abacus junior vet haematological analyzer. LDL-cholesterol fraction 
Vol. 19(2010): 223-232.

was calculated from the formula: $\mathrm{LDL}=$ total cholesterol - (TG/5 + HDL-cholesterol).

All the results from the analytical laboratory were performed in two replications.

\section{Statistical analysis}

The results obtained were analyzed statistically (standard error of means (SEM), standard deviation (SD) and effects of diets) by ANOVA and analysis of variance with the Duncan's multiple range test, using Statistica 6.0 software (StatSoft 1995). The $p$ value $\leq 0.01$ and 0.05 was considered significant.

\section{Results and Discussion}

Table 4 presents the results of growth performance and pig carcass characteristics. The use of raw grass pea seeds amounting to $50 \%$ of protein feeds in finisher diet did not result in lower growth performance in comparison to the control group. However, the fatteners fed grass pea seeds amounting to $50 \%$ of protein feedstuffs in both fattening periods revealed the highest feed and energy intake per $\mathrm{kg}$ of live weight gain, compared to the group feed grass pea only in the second phase of the fattening period. A higher share of grass pea seeds in the mixture $(100 \%$ protein feed) led to weaker growth performance and carcass characteristics.

In both fattening periods daily live weight gains in the animals fed with raw grass pea amounting to $100 \%$ of protein feedstuffs were significantly $(p \leq 0.01)$ lower in comparison to the remaining groups. Similar tendencies were noted by other authors (Castell et al. 1994, Winiarska-Mieczan 2002). The animals in this particular experimental group also revealed a significantly lower weight of ham, compared to the other groups. The reason of this a decrease in the weight of ham may be a weaker synthesis of meat tissues, resulting from lower protein absorption in the feed caused by e.g. $\beta$-ODAP content (Hanbury et al. 2000). The high content of antinutritional agents in raw grass pea seeds and differences in the protein and amino acid digestibility between grass pea seeds and soybean meal may be also responsible for lower growth performance. Little information on amino acid and protein availabilities of grass pea seeds in animals was published so far. The studies in rats revealed that true digestibility of Lathyrus sativus seeds protein was high (90\%) (Hanczakowski et al. 1997). In an in vitro experiment Monsoor and Yusuf (2002) showed that the raw grass pea seeds protein digestibility was about 93.4\%. However, according to Trombetta et al. (2006) crude protein digestibility, calculated for diets which contained $20 \%$ soybean meal and $10 \%$ raw grass pea seeds, and $15.5 \%$ soybean meal and $20 \%$ grass pea were about $85 \%$, and was similar to the digestibility of diet containing soybean meal as the only source of plant protein. The coefficients of digestibility indicate that soybean meal can be replaced with grass pea seeds. A significant decrease in the fat content of the animals in the group receiving raw grass pea seeds amounting to $100 \%$ of protein feeds throughout the whole fattening period (group IV) may be explained as resulting from the content of substances limiting the use of the feed's energetic components. The layer of thickness backfat in these animals was lower than as about $24 \%$ in comparison to the other fatteners. Similar results were obtained in the author's own studies (WiniarskaMieczan 2002).

On the other hand, the fatteners fed grass pea seeds amounting to $50 \%$ of protein feedstuffs (group III) revealed the highest feed and energy intake per kg of live weight gain. The highest protein intake per $\mathrm{kg}$ of live weight gain was observed in the animals administered raw grass pea seeds amounting to $100 \%$ of protein feeds in both fattening periods (group IV). However, in the grower period, pigs fed a diet with $100 \%$ grass pea seeds had higher $(p \leq 0.05)$ energy intake than control group.

Using raw seeds of grass pea only in the second phase of the fattening period (group II) did not lead to any significant $(p \leq 0.01)$ increase in the weight of the liver and kidneys, neither did it affect the basic chemical composition of these organs (Table 5). However, the consumption of raw grass 
Winiarska-Mieczan and Kwiecień. Influence of grass pea seeds on pig performance and blood parameters

Table 4. Results of pig carcass characteristics (mean \pm sd).

\begin{tabular}{|c|c|c|c|c|c|c|}
\hline & \multicolumn{4}{|c|}{ Feeding groups } & \multirow{2}{*}{ SEM } & \multirow{2}{*}{$\begin{array}{l}\text { Effects } \\
\text { of diet }\end{array}$} \\
\hline & I & II & III & IV & & \\
\hline $\mathrm{n}$ & 24 & 24 & 24 & 24 & & \\
\hline Fattening days & 100 & 100 & 100 & 104 & 0.03 & NS \\
\hline \multicolumn{7}{|l|}{ Body weight, $\mathrm{kg}$} \\
\hline Initial & $25.4 \pm 1.5$ & $25.3 \pm 1.5$ & $25.1 \pm 1.4$ & $25.3 \pm 1.3$ & 0.02 & NS \\
\hline Final & $100 \pm 8.8$ & $99.8 \pm 8.3$ & $100 \pm 5.4$ & $100 \pm 6.9$ & 0.15 & NS \\
\hline \multicolumn{7}{|l|}{ Daily live weight gain, $g$} \\
\hline Grower period & $658^{\mathrm{b}} \pm 26.1$ & $645^{b} \pm 27.9$ & $665^{\mathrm{b}} \pm 28.4$ & $601^{\mathrm{a}} \pm 25.5$ & 16.35 & * \\
\hline Finisher period & $872^{b} \pm 33.3$ & $849^{b} \pm 27.4$ & $859^{b} \pm 26.8$ & $801^{\mathrm{a}} \pm 32.1$ & 22.32 & * \\
\hline Overall & $765^{\mathrm{b}}$ & $747^{\mathrm{b}}$ & $762^{\mathrm{b}}$ & $701^{\mathrm{a}}$ & 15.15 & * \\
\hline $\mathrm{n}$ & 10 & 10 & 10 & 10 & & \\
\hline Dressing percentage, $\%$ & $82.6 \pm 5.3$ & $82.4 \pm 4.1$ & $80.7 \pm 4.7$ & $80.8 \pm 4.9$ & 1.14 & NS \\
\hline Carcass length, $\mathrm{cm}$ & $80.6^{\mathrm{b}} \pm 5.7$ & $82.4^{b} \pm 6.3$ & $78.3^{b} \pm 4.1$ & $72.5^{\mathrm{a}} \pm 4.1$ & 0.47 & $* *$ \\
\hline Carcass weight, $\mathrm{kg}$ & $82.1^{\mathrm{b}} \pm 6.8$ & $81.9^{b} \pm 7.1$ & $78.1^{b} \pm 5.6$ & $75.6^{\mathrm{a}} \pm 6.9$ & 0.71 & $* *$ \\
\hline Proper ham weight, $\mathrm{kg}$ & $6.40^{\mathrm{b}} \pm 0.5$ & $6.11^{\mathrm{b}} \pm 0.7$ & $6.30^{b} \pm 0.3$ & $5.30^{\mathrm{a}} \pm 0.4$ & 0.10 & * \\
\hline Loin eye area, $\mathrm{cm}^{2}$ & $48.5 \pm 2.5$ & $48.1 \pm 2.8$ & $47.4 \pm 1.5$ & $48.1 \pm 2.2$ & 1.12 & NS \\
\hline Backfat thickness, cm *** & $1.72^{\mathrm{b}}$ & $1.77^{\mathrm{b}}$ & $1.74^{\mathrm{b}}$ & $1.51^{\mathrm{a}}$ & 0.28 & * \\
\hline Leaf fat, $\mathrm{kg}$ & $0.70^{\mathrm{a}} \pm 0.04$ & $0.67^{\mathrm{a}} \pm 0.04$ & $0.86^{b} \pm 0.05$ & $0.68^{\mathrm{a}} \pm 0.03$ & 0.11 & * \\
\hline $\mathrm{n}$ & 12 & 12 & 12 & 12 & & \\
\hline \multicolumn{7}{|c|}{ Feed intake, $\mathrm{kg}$ per kg live weight gain } \\
\hline Grower period & $3.27^{\mathrm{a}} \pm 0.10$ & $3.25^{\mathrm{a}} \pm 0.11$ & $3.32^{\mathrm{a}} \pm 0.15$ & $3.62^{b} \pm 0.09$ & 0.06 & * \\
\hline Finisher period & $3.83^{\mathrm{ab}} \pm 0.10$ & $3.91^{\mathrm{ab}} \pm 0.21$ & $4.38^{b} \pm 0.12$ & $3.34^{\mathrm{a}} \pm 0.20$ & 0.10 & * \\
\hline Overall & $3.55^{\mathrm{a}}$ & $3.58^{\mathrm{a}}$ & $3.85^{\mathrm{b}}$ & $3.48^{\mathrm{a}}$ & 0.05 & * \\
\hline \multicolumn{7}{|c|}{ Protein intake, g per kg live weight gain } \\
\hline Grower period & $577^{\mathrm{a}} \pm 41.2$ & $573^{\mathrm{a}} \pm 35.1$ & $566^{\mathrm{a}} \pm 41.2$ & $621^{\mathrm{b}} \pm 40.1$ & 12.83 & * \\
\hline Finisher period & $586^{\mathrm{b}} \pm 36.1$ & $592^{b} \pm 25.2$ & $662^{\mathrm{c}} \pm 35.1$ & $510^{\mathrm{a}} \pm 37.1$ & 9.56 & * \\
\hline Overall & $581^{\mathrm{a}}$ & $582^{\mathrm{a}}$ & $614^{\mathrm{ab}}$ & $565^{\mathrm{b}}$ & 7.68 & * \\
\hline \multicolumn{7}{|c|}{ Energy intake, MJ per kg live weight gain } \\
\hline Grower period & $41.9^{\mathrm{a}} \pm 2.1$ & $41.6^{\mathrm{a}} \pm 3.5$ & $42.8^{\mathrm{a}} \pm 4.0$ & $46.7^{\mathrm{b}} \pm 3.2$ & 0.72 & $* *$ \\
\hline Finisher period & $48.3^{\mathrm{b}} \pm 3.0$ & $49.3^{\mathrm{b}} \pm 2.9$ & $55.2^{\mathrm{c}} \pm 2.8$ & $42.7^{\mathrm{a}} \pm 2.9$ & 1.18 & $* *$ \\
\hline Overall & $45.1^{\mathrm{a}}$ & $45.4^{\mathrm{a}}$ & $49.0^{\mathrm{b}}$ & $44.7^{\mathrm{a}}$ & 0.52 & $* *$ \\
\hline
\end{tabular}

NS- not significant

a, b, c- means in the same row with different superscripts differ significantly

*** mean from 5 measurements 
Vol. 19(2010): 223-232.

Table 5. Effects of raw grass pea seeds on kidney and liver weights, and chemical composition of kidney and liver in pigs (mean $\pm \mathrm{sd})$.

\begin{tabular}{|c|c|c|c|c|c|c|}
\hline & \multicolumn{4}{|c|}{ Feeding groups } & \multirow{2}{*}{ SEM } & \multirow{2}{*}{$\begin{array}{c}\text { Effects of } \\
\text { diets }\end{array}$} \\
\hline & I & II & III & IV & & \\
\hline $\mathrm{n}^{1}$ & 10 & 10 & 10 & 10 & & \\
\hline Kidney weight, g & $150^{\mathrm{a}} \pm 30.1$ & $157^{\mathrm{a}} \pm 12.4$ & $166^{\mathrm{ab}} \pm 10.3$ & $171^{\mathrm{b}} \pm 9.8$ & 6.61 & $*$ \\
\hline Liver weight, $\mathrm{g}$ & $1638^{\mathrm{a}} \pm 256.0$ & $1658^{\mathrm{a}} \pm 220.0$ & $1703^{\mathrm{a}} \pm 235.1$ & $1905^{\mathrm{b}} \pm 211.4$ & 11.05 & $*$ \\
\hline \multicolumn{7}{|c|}{ Chemical composition of liver, $\%$} \\
\hline Dry matter & $26.1 \pm 5.8$ & $26.2 \pm 4.1$ & $26.1 \pm 5.0$ & $26.7 \pm 4.6$ & 0.02 & NS \\
\hline Crude protein & $20.6 \pm 3.9$ & $20.5 \pm 21$ & $20.6 \pm 4.2$ & $20.2 \pm 4.5$ & 0.02 & NS \\
\hline Crude ash & $1.68^{\mathrm{bc}} \pm 0.05$ & $1.78^{\mathrm{c}} \pm 0.02$ & $1.65^{\mathrm{b}} \pm 0.03$ & $1.40^{\mathrm{a}} \pm 0.03$ & 0.03 & $*$ \\
\hline Crude fat & $3.73^{\mathrm{a}} \pm 0.8$ & $3.82^{\mathrm{a}} \pm 0.4$ & $3.77^{\mathrm{a}} \pm 0.4$ & $4.97^{\mathrm{b}} \pm 0.5$ & 0.02 & $*$ \\
\hline \multicolumn{7}{|c|}{ Chemical composition of kidney, $\%$} \\
\hline Dry matter & $16.3^{\mathrm{a}} \pm 3.2$ & $16.3^{\mathrm{a}} \pm 2.8$ & $17.3^{\mathrm{b}} \pm 2.7$ & $17.2^{\mathrm{b}} \pm 3.1$ & 0.15 & $*$ \\
\hline Crude protein & $13.6 \pm 2.1$ & $13.6 \pm 2.0$ & $13.9 \pm 2.5$ & $14.0 \pm 2.0$ & 0.12 & NS \\
\hline Crude ash & $1.19^{\mathrm{a}} \pm 0.08$ & $1.21^{\mathrm{a}} \pm 0.08$ & $1.52^{\mathrm{b}} \pm 0.07$ & $1.16^{\mathrm{a}} \pm 0.06$ & 0.02 & $*$ \\
\hline Crude fat & $1.46^{\mathrm{a}} \pm 0.08$ & $1.42^{\mathrm{a}} \pm 0.1$ & $1.79^{\mathrm{b}} \pm 0.06$ & $2.01^{\mathrm{c}} \pm 0.03$ & 0.01 & $*$ \\
\hline
\end{tabular}

NS- not significant

$* \mathrm{p} \leq 0.01$

a, b, c - means in the same row with different superscripts differ significantly

SEM - standard error of the means

${ }^{1}$ three replicates assayed per sample

pea seeds by grower-finisher pigs in both fattening periods (group IV) contributed to an increase in the weight of the liver and kidney more than $10 \%$. The observations were in according to the results of the studies performed by other authors (Castell et al. 1994, Pontif et al. 1987). Similar tendencies were noted in the experiments carried out on beef cattles (Grela et al. 1997). The increase in the weight of the liver and kidney results from intensified processes of removing anti-nutrient substances from the organism. The greater weight and fat content in liver could be attribute to protein metabolism (Chen et al. 1999). According to Bugianesi et al. (2005) hepatic fat deposition is correlated with liver damage. The increase in fat content of liver in treatment IV indicated the damage of this organ.

Table 6 presents some chosen biochemical and haematological parameters, as well as a leukogram of grower-finisher pigs' blood in both fattening periods. The mean values of biochemical and haematological parameters obtained by sampling of grower-finisher pigs fed with share of raw seeds of grass pea are in according to the data reported by Winnicka (2004). However, an increased level of certain parameters in comparison with the control group was noted, which could result from ontogenetic traits.

At the same time, in the grower fattening period a higher activity of alanine aminotransferase (ALAT) and aspartate aminotransferase (ASAT) in comparison with the other experimental groups was determined in the samples of animals receiving the seeds of grass pea.

In the finisher fattening period the blood of the animals from group IV (raw seeds of grass pea amounting to $100 \%$ of protein feeds) revealed a higher activity of ASAT and ALAT than those groups. In this group the activity of alkaline phosphatase (ALP) was also significantly $(p \leq 0.01)$ higher in comparison with the other feeding groups.

A high level of ASAT and ALAT could highlight a greater activity is a measure of the degree 
Winiarska-Mieczan and Kwiecień. Influence of grass pea seeds on pig performance and blood parameters

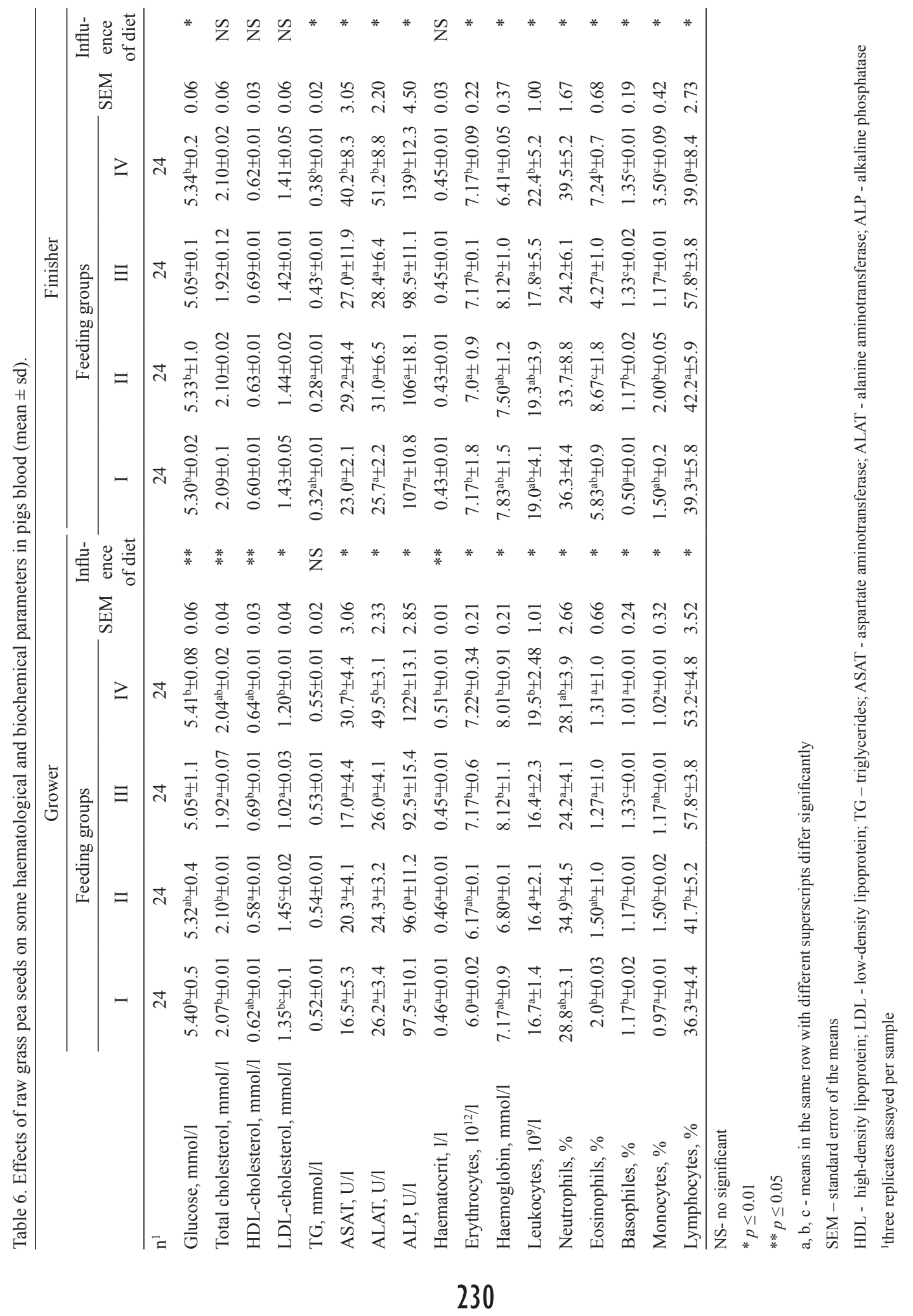


Vol. 19(2010): 223-232.

of the liver's damage and malfunction (Gole and Dasgupta 2002, Ksheerasagar and Kaliwa 2006, Kwiecien et al. 2006). The increased activity of ALP may also suggest problems in the functioning of this organ (Gole and Dasgupta 2002, Yakubu et al. 2005). An elevated level of these enzymes noted exclusively in the animals receiving a mixture with the highest share of raw grass pea seeds was probably caused by the adverse influence of anti-nutrient substances present in the diet, particularly of $\beta$-ODAP, on the liver. The reason could be also an intensified process of the removal of toxic substances from the organism.

The blood of the grower-finisher pigs in group IV also revealed a significant level of $(p \leq 0.01)$ leukocytes than in the other experimental groups. In the study performed by Grela et al. (1998), determining the nutritional utility of raw grass pea seeds for guinea pigs, an increased content of leukocytes in experimental groups was detected, in comparison with the control groups. The increase in the content of leukocytes may indicate some damage of tissues, for example of the liver (Jaeschke 1997). It is significant that the liver of those animals revealed hypertrophy (Table 5). Using a mixture with an excessive share of raw grass pea seeds may negatively affect the metabolism of this organ. Studies performed on rats proved that the elements included in the seeds of grass pea affect the enzymatic activity of the liver (Zipser et al. 1997). The authors observed that an increase in the share of seeds in the diet leads to an increase in the activity of $\gamma$-glutamylotranspeptidase, a liver enzyme whose activity is closely related to the detoxicating cytochrome P-450. This enzyme is regarded as a very sensitive indicator of the functional state of the liver.

\section{Conclusions}

The use of raw grass pea seeds amounting to $50 \%$ of protein feeds in finisher diet did not result in lower growth performance in comparison to the control group. However, the fatteners fed grass pea seeds amounting to $50 \%$ of protein feedstuffs in both fattening periods revealed the highest feed and energy intake per kg of live weight gain, compared to the group feed grass pea only in the second phase of the fattening period. A positive correlation between the activity of ALAT, ASAT and ALP and the content of raw grass pea seeds in a feeding dose was noted. The increased level of these enzymes was determined exclusively in the animals fed in both fattening periods with a mixture in which the seeds of grass pea were the only source of plant protein. It is also noteworthy that the liver of those animals revealed hypertrophy. This probably resulted from an adverse influence of anti-nutrient substances ( $\beta$-ODAP in particular) present in grass pea seeds on the liver. Using raw seeds of grass pea amounting to $50 \%$ of total protein feeds, solely in the finisher fattening period did not result in a significant increase in the weight of the liver and kidney, nor did it affect the activity of ALAT, ASAT and ALP. However, the consumption of raw grass pea seeds $(50 \%$ of protein feeds) by grower-finisher pigs in both fattening periods contributed to an increase in the weight of the liver and kidney more than $10 \%$, which did not have any considerable influence on the activity of the enzymes marked.

\section{References}

AOAC (1990): Official Methods of Analysis. Association of Official Analytical Chemists. Inc., Arlington, Wirginia.

Bugianesi, E., Pagotto, U., Manini, R., Vanni, E., Gastaldelli, A., de lasio, R., Gentilcore, E., Natale, S., Cassader, M., Rizzetto, M., Pasquali, R. \& Marchesini, G. 2005. Plasma adiponectin in nonalcoholic fatty liver is related to hepatic insulin resistance and hepatic fat content, not to liver disease severity. Journal of Clinical Endocrinology \& Metabolism 90: 3498-3504.

Castell, A.G., Cliplef, R.L., Briggs, C.J., Cambell, C.G. \& Bruni, J.E. 1994. Evaluation of lathyrus (Lathyrus sativus L.) as an ingredient in pig starter and grower diets. Canadian Journal of Animal Science 74: 529-539.

Chen, H.Y., Lewis, A.J., Miller, P.S. \& Yen, J.T. 1999. The effect of excess protein on growth performance and protein metabolism of finishing barrows and gilts. Journal of Animal Science 77: 3238-3247.

Getahun, H., Mekonnen, A., Tekle Haimanot, R. \& Lambein, F. 1999. Epidemic of neurolathyrism in Ethiopia. Lancet 354: 306-307. 


\section{AGRICULTURAL AND FOOD SCIENCE}

Winiarska-Mieczan and Kwiecień. Influence of grass pea seeds on pig performance and blood parameters

Gole, M.K. \& Dasgupta, S. 2002. Role of plant metabolites in toxic liver injury. Asia Pacific Journal of Clinical Nutrition 11: 48-50.

Grela, E.R., Czech, A., Winiarska, A. \& Fiołka, M. 1998. Effects of dietary supplementation of grass pea (Lathyrus sativus L.) seeds on performance and some parameters of blood giunea pigs (Calvia porcella). Annales Univ. Mariae Curie-Skłodowska (sectio EE) 43: 329-334. (in Polish, English abstract)

Grela, E.R., Matras, J., Florek, M., Litwińczuk, A., Barłowska, J., Winiarska, A. \& Wacław, D. 1997. Effect of flat pea (Lathyrus sativus L.) seeds in blef cattle feeding on performance and carcass trait. In: International Symposium: Lathyrus sativus - cultivation and nutritive value in animals and humans. Radom, Poland, p. 134-139. (in Polish, English abstract

Grela, E.R., Studzinski, T. \& Matras, J. 2001. Antinutritional factors in seeds of Lathyrus sativus cultivated in Poland. Lathyrus Lathyrism Newsletter 2: 101-104.

Hanbury, C.D., White, C.L., Mullan, B.P. \& Siddique, K.H.M. 2000. A review of the potential of Lathyrus sativus $L$. and $L$. cicera L. grain for use as animal feed. Animal Feed Science and Technology 87: 1-27.

Hanczakowski, P., Szymczyk, B., Pisulewska, E. \& Ernest, T. 1997. Comparison of composition and nutritive value of chickling vetch (Lathyrus sativus) pea and soybean seed. In: International Symposium: Lathyrus sativus cultivation and nutritive value in animals and humans. Radom, Poland, p. 56-58. (in Polish, English abstract)

Jaeschke, H. 1997. Cellular adhesion molecules: regulation and functional significance in the pathogenesis of liver diseases. American Journal of Physiology 273: 602-611.

Jyothi, P., Pratap Rudra, M.P. \& Rao, S.L.N. 1998. In vivo metabolism of $\beta-\mathrm{N}$-oxalyl-I- $\alpha, \beta$-diaminopropionic acid: the Lathyrus sativus neurotoxin in experimental animals. Natural Toxins 6: 189-195.

Kakade, M.J., Rackis, I.J., McGheen, J.E. \& Puski, G. 1974. Determination of trypsin inhibitor activity of soy products: a collaborative analysis of an improved procedure. Cereal Chemistry 51: 376-382.

Ksheerasagar, R.L. \& Kaliwa, B.B. 2006. Histological and biochemical changes in the liver of albino mice on exposure to insecticide, carbosulfan. Caspian Journal of Environmental Sciences 4: 67-70.

Kuo, Y.H., Bau, H.M., Quemener, B., Khan, J.K. \& Lambein, F. 1995. Solid-state fermentation of Lathyrus sativus seeds using Aspergillus oryzae and Rhizopus oligosporus sp T-3 to eliminate the neurotoxin beta-ODAP without loss of nutritional value. Journal of the Science of Food and Agriculture 69: 81-89.

Kuo, Y.-H., Defoort, B., Getahun, H., Tekle-Haimanot, R. \& Lambein, F. 2007. Comparison of urinary amino acids and trace elements (copper, zinc and manganese) of recent neurolathyrism patients and healthy controls from Ethiopia. Clinical Biochemistry 40: 397-402.

Kwiecień, M., Winiarska-Mieczan, A. \& Kapica, M. 2006. The influence of some herbs on chemical composition, lipid metabolism indices, ALAT and ASAT activity in broiler chicken liver. Polish Journal of Natural Sciences 3(Suppl.): 439-444.
Lambein, F., Khan, J.K., Kuo, Y-H., Campbell, C.G. \& Briggs, C.J. 1993. Toxins in the seedlings of some varieties of grass pea (Lathyrus sativus). Natural Toxins 1: 246-249.

Monsoor, M.A., Yusuf, H.K.M. 2002. In vitro protein digestibility of lathyrus pea (Lathyrus sativus), lentil (Lens culinaris), and chickpea (Cicer arietinum). International Journal of Food Science and Technology 37: 97-99.

Pontif, J.E., Southern, L.L., Coombs, D.F., McMillin, K.W., Bidner, T.D. \& Watkins, K.L. 1987. Gain, feed efficiency and carcass quality of finishing swine fed raw soybean. Journal of Animal Science 64: 177-181.

Pratap Rudra, M.P., Raghuveer Singh, M., Junaid, M.A., Jyothi, P. \& Rao, S.L.N. 2004. Metabolism of dietary ODAP in humans may be responsible for the low incidence of neurolathyrism. Clinical Biochemistry 37 : 318-322.

Ramachandran, S. \& Ray, A.K. 2004. Inclusion of extruded grass pea, Lathyrus sativus seed meak in compound diets for rohu, Labeo rohita (Hamilton, 1822) fingerlings. Acta Ichthyologica et Piscatoria 34: 205-218.

Ramachandran, S., Bairagi, A. \& Ray, A.K. 2005. Improvement of nutritive value of grass pea (Lathyrus sativus) seed meal in the formulated diets for rohu, Labeo rohita (Hamilton) fingerlings after fermentation with a fish gut bacterium. Bioresource Technology 96: 1465-1472.

Różycki, M. 1996. Results of pigs tested at pig testing stations. Report on pig breeding in Poland. Inst. Zootech. Kraków, Poland. (in Polish)

Sharma, A., Kalia, M. \& Malhotra, S.R. 2003. Effect of antinutritional factors in khesari seeds (Lathyrus sativus) on the biological performance of chicks. Lathyrus Lathyrism Newslatter 3: 41-43.

StatSoft Inc. 1995. Statistica for Windows. Tulsa: StatSoft.

Trombetta, M.F., Mattii, S., Pasquini, M. \& Falaschini, A. 2006. Evaluation of the digestibility of Lathyrus sativus in growing pigs. Italian Journal of Animal Science 5: 147-153.

Winiarska-Mieczan, A. 2002. Effectives of grass pea (Lathyrus sativus $L$.) seeds in the growing-finishing pig diet. Annales Univ. Mariae Curie-Skłodowska (sectio EE) 20: 357-363. (in Polish, English abstract)

Winiarska-Mieczan, A. 2010. The influence of grass pea seeds in pig diets on the fatty acid composition and sensory attributes of pork. Medycyna Weterynaryjna 66: 113-117.

Winnicka, A. 2004. Reference values of basic laboratory tests in veterinary. Warsaw Agricultural University (SGGW) Publisher, Warsaw. (in Polish)

Yakubu, M.T., Adebayo, O.J., Egwim, E.C. \& Owoyele, V.B. 2005. Increased liver alkaline phosphatase and aminotransferase activities following administration of ethanolic extract of Khaya senegalensis stem bark to rats. Biokemistri 17: 27-32.

Zipser, J., Grela, E.R., Valvedre Piedra, J.L. \& Sadurska, A. 1997. Influence of dietary supplementation of raw and extruded flat pea seeds (Lathyrus sativus L.) on glycogen and anzymes in the liver of rats. In: International Symposium: Lathyrus sativus - cultivation and nutritive value in animals and humans. Radom, Poland, p. 118122. (in Polish, English abstract) 